\title{
Seismic and chronostratigraphic results from SHALDRIL II, northwestern Weddell Sea
}

\author{
J. B. Anderson, ${ }^{1}$ J. Wellner, ${ }^{2}$ S. Wise, ${ }^{3}$ S. Bohaty, ${ }^{4}$ P. Manley, ${ }^{5}$ T. Smith, ${ }^{6}$ F. Weaver, ${ }^{7}$ and D. Kulhanek ${ }^{8}$ \\ ${ }^{1}$ Department of Earth Science, Rice University, Houston, TX 77251-1892, USA (johna@rice.edu) \\ ${ }^{2}$ Department of Geosciences, University of Houston, Houston, Texas 77204-5007 (jwellner@uh.edu) \\ ${ }^{3}$ Department of Geological Sciences, Florida State University, Tallahassee, FL 32306-4100, USA (wise@gly.fsu.edu) \\ ${ }^{4}$ Department Earth and Planetary Sciences, University of California at Santa Cruz, Santa Cruz, CA (sbohaty@es.ucsc.edu) \\ ${ }^{5}$ Department of Geology, Middleburry College, 427 McCardell Bicentennial Hall, Middleburry, VT, 05735 (manley@middleburry.edu) \\ ${ }^{6}$ Department of Earth Science, Rice University, Houston, TX 77251-1892, USA (rtsmith@rice.edu) \\ ${ }^{7}$ Department of Earth Science Rice University, Houston, TX 77251-1892, USA (fred.m.weaver@sbcglobal.net) \\ ${ }^{8}$ Department of Geological Sciences, Florida State University, Tallahassee, FL 32306-4100, USA (kulhanek@gly.fsu.edu)
}

\begin{abstract}
The 2006 SHALDRIL II cruise was conducted in the northwestern Weddell Sea, with primary drilling targets in the James Ross Basin. A site drilled along the northern edge of the James Ross Basin sampled either latest Eocene or earliest Oligocene deposits, providing a lower chronostratigraphic benchmark for our seismic stratigraphic age model. Severe sea ice conditions forced abandonment of several of the James Ross Basin sites. Three alternate sites were drilled along the southern flank of the Joinville Plateau. Seismic data from the area show a thick, southward dipping stratigraphic succession with no conspicuous gaps. Three drill sites sampled this succession and recovered Oligocene, middle Miocene, and early Pliocene strata overlain by a thin drape of Pleistocene deposits. The PlioceneMiocene boundary appears to be represented by a disconformity within the cored interval. Otherwise, this is one of the most complete post-Eocene successions anywhere on Antarctica and its adjacent margins.

Citation: Anderson, J.B., J. Wellner, S. Wise, S. Bohaty, P. Manley, T. Smith, F. Weaver, and D. Kulhanek (2007), Seismic and Chronostratigraphic Results from SHALDRIL II, Northwestern Weddell Sea, in Antarctica: A Keystone in a Changing World--Online Proceedings of the 10 ${ }^{\text {th }}$ ISAES X, edited by A.K. Cooper and C.R. Raymond et al., USGS Open-File Report 2007-1047, Short Research Paper 094, 4 p.; doi:10.3133/of2007-1047.srp094
\end{abstract}

\section{Introduction}

Our understanding of Antarctica's Cenozoic climate evolution and ice sheet development has increased slowly over the decades. The greatest hindrance to progress on this front has been a paucity of outcrops and long sediment cores that sample Cenozoic strata.

All around the Antarctic continent, seaward dipping strata have been deeply eroded by the ice sheet when it advanced onto the continental shelf. Older strata occur just beneath the seafloor where they can be imaged using high-resolution seismic methods. When combined with chronostratigraphic data from drill core, it is possible to construct relatively detailed records of eustatic and climatic controls on continental shelf evolution, including a record of ice sheet expansion and decay over time. The concept behind SHALDRIL is to drill through the glacial section and sample older deposits. It is not intended to acquire very long core, but rather to rely on seismic stratigraphy as a framework for establishing the climatic and glacial history of the shelf and well-placed drill core to corroborate these interpretations and provide chronostratigraphic control. The success of this method is dependent upon having a mobile drilling platform, capable of operating in ice-covered waters, and a drilling system that can retrieve core in a matter of hours. A robust seismic stratigraphic framework enables selection of numerous sites, which increases the odds of being able to sample the desired stratigraphic targets where ice conditions allow.

Another important aspect of SHALDRIL is that condensed sections (e.g., onlap of reflections) are targeted because they have the greatest likelihood of yielding suitable fossil material for biostratigraphic analysis. SHALDRIL II was a good test of this strategy because severe ice conditions prevented drilling any of the primary sites. Yet, each of the stratigraphic targets was sampled and each site yielded microfossils for age determination.

SHALDRIL II was conducted in the northwestern Weddell Sea and the primary drilling targets were in the northern portion of the James Ross Basin, which is known to contain one of the thickest, most complete Cenozoic successions anywhere on Antarctica and its adjacent margins (Anderson, 1999). The drilling targeted latest Eocene through Pleistocene strata, based on a seismic stratigraphic age model for James Ross Basin.

\section{Seismic stratigraphy and age model for the James Ross Basin}

Our original seismic stratigraphic framework and age model for the James Ross Basin were based on a grid of seismic data acquired during 1991 (Anderson et al., 1992) using the R/V Polar Duke as a platform (Figure 1). These data were later augmented by seismic profiles acquired farther south in the more central part of the basin (Sloan et al., 1995). Anderson (1999) merged the seismic data from both areas and assigned preliminary ages to the seismic units based on similarities in stratigraphic architectures between the James Ross Basin and the continental shelf on the northern side of the Peninsula. Two long strike lines were later collected during our 2002 NB Palmer cruise that provided important ties between the Polar Duke and Palmer data sets (Fig. 1).

The 1991 data set included a key line (PD91-28A) 


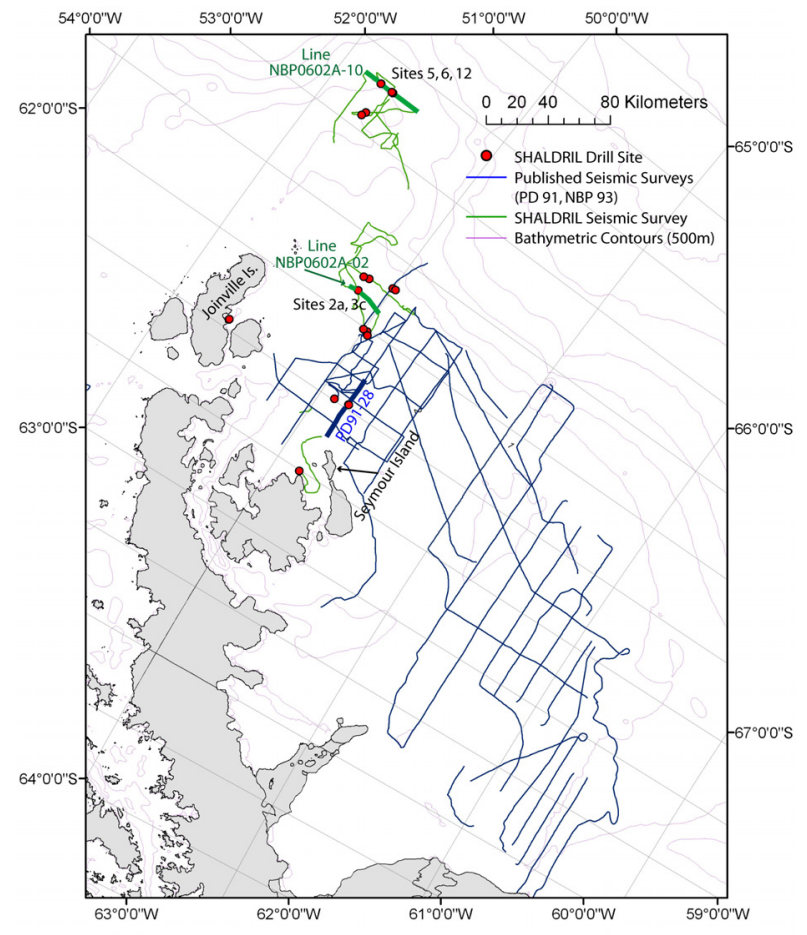

Figure 1. Locations of seismic data used to locate drill sites. that extends from the shelf margin to the Antarctic Sound, crossing north of Seymour Island. This line was acquired So as to cross the projected strike of the Seymour Island strata, thus providing a rough upper Eocene to lower Oligocene stratigraphic benchmark for the base of the section. The lower part of the stratigraphic section offshore of Seymour Island is an acoustically laminated unit (Unit S5) that is between 1.2 and 1.5 kilometers thick.

A prominent onlap surface near the middle of Unit S5 was traced around the northern edge of the basin and drilled at Site 3c (Figure. 2). Site 3c core yielded a microfossil assemblage with an age of between 37 and 32 Ma. Our interpretation is that this surface corresponds to a prominent lowstand and associated oxygen isotope excursion at $34 \mathrm{Ma}$ (Zachos et al., 2001). The seismic data indicate that during the late Eocene and Oligocene, the northern James Ross Basin was being filled by discrete depocenters around the margin of the basin. There is no evidence of glacial erosion and associated mass wasting during this time interval.

\section{Seismic stratigraphy of the Joinville Plateau}

During SHALDRIL II extensive, very thick multiyear sea ice prevented us from occupying the primary sites that were needed to test the age model for the younger part of the section in the James Ross Basin. As a result, the study area was shifted to a region of more open water, east of Joinville Island (Figure 1). Seismic data from this

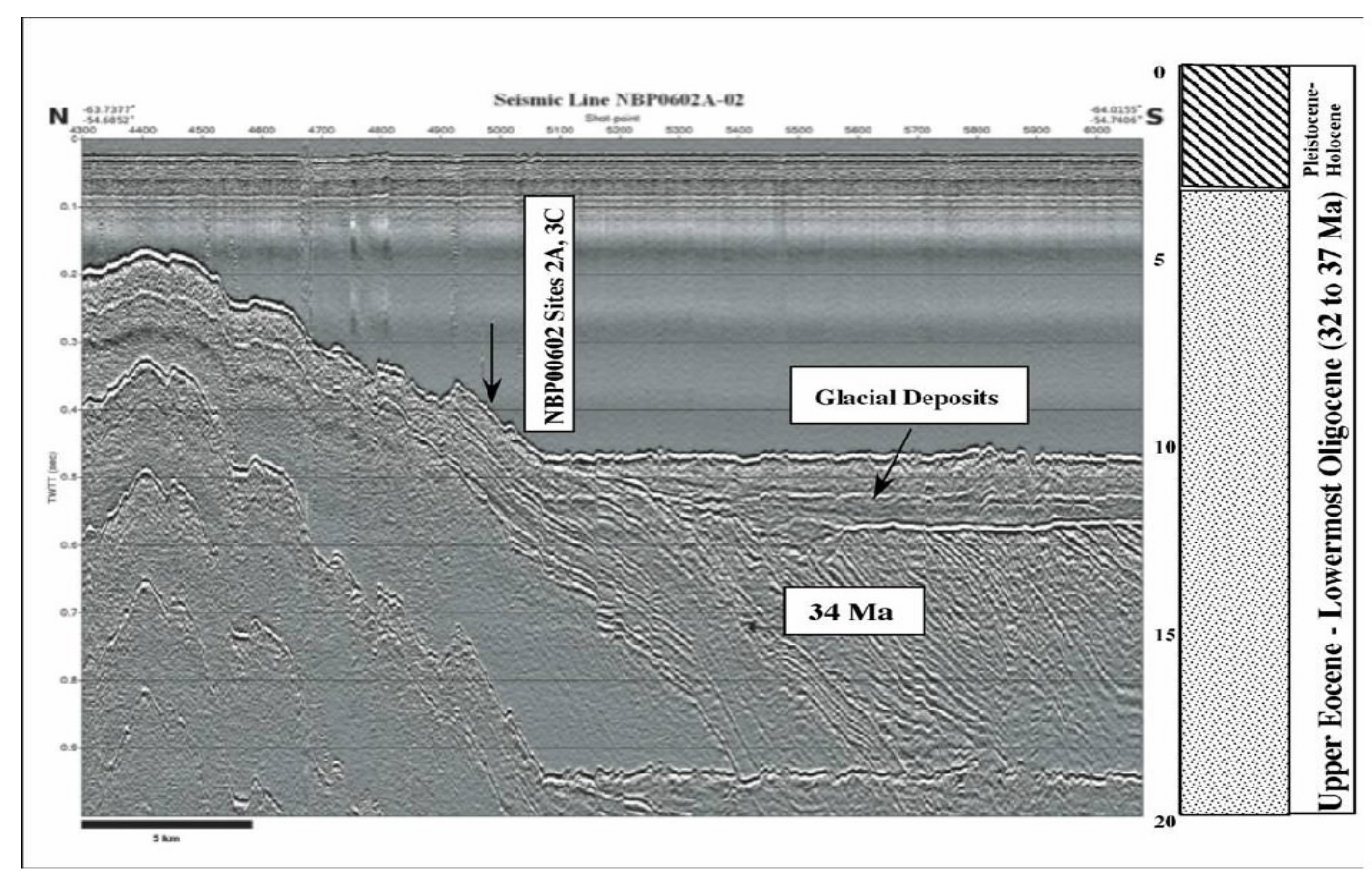

Figure 2. A segment of seismic line NBP 0602A-02 showing the latest Eocene to early Oligocene onlap surface sampled at SHALDRIL II site 3C. See Figure 1 for location. 


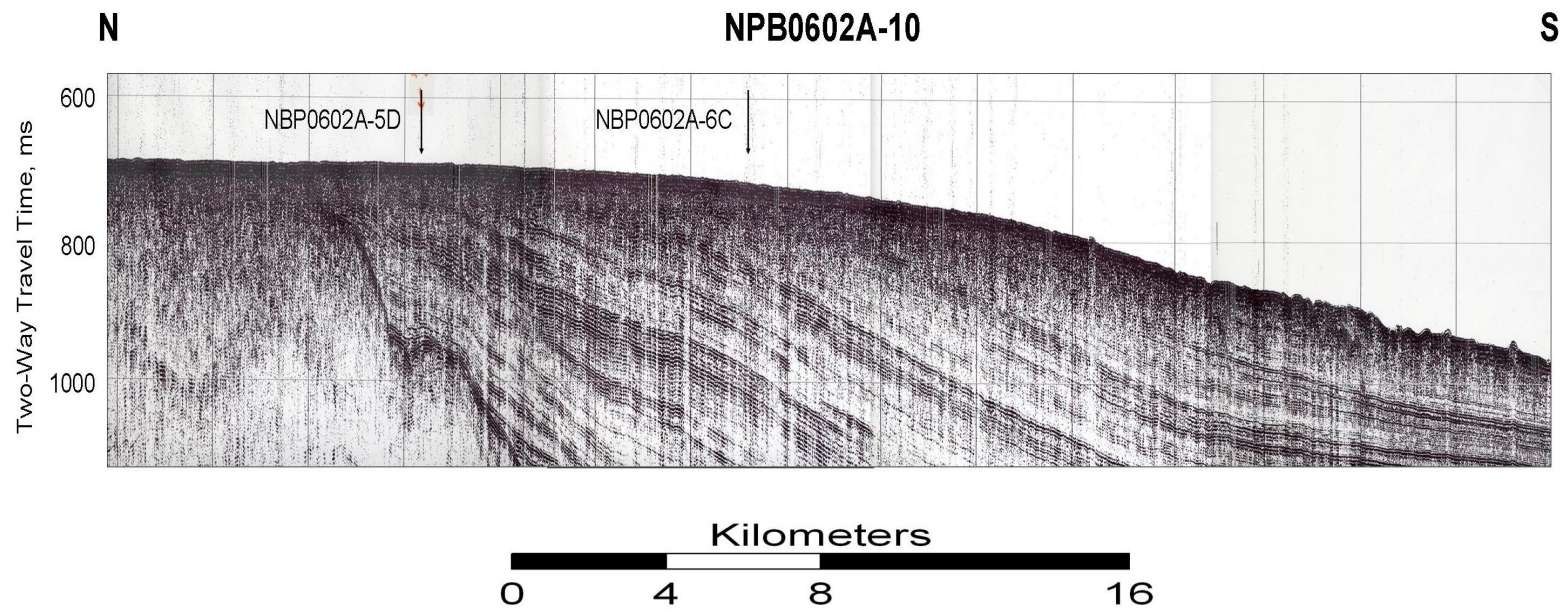

Figure 3. Seismic profile NBP 0602A-10 crosses the southern flank of the Joinville Plateau and is used to illustrate the thick Cenozoic stratigraphic section targeted during SHALDRIL II. Note the strongly reflective horizons that are interpreted as condensed sections. Also shown are the locations of drill sites NBP 0602A-5 and 6. Site NBP 0602A-12 was collected on an adjacent line and updip of Site NBP 0602A-5. See Figure 1 for location.

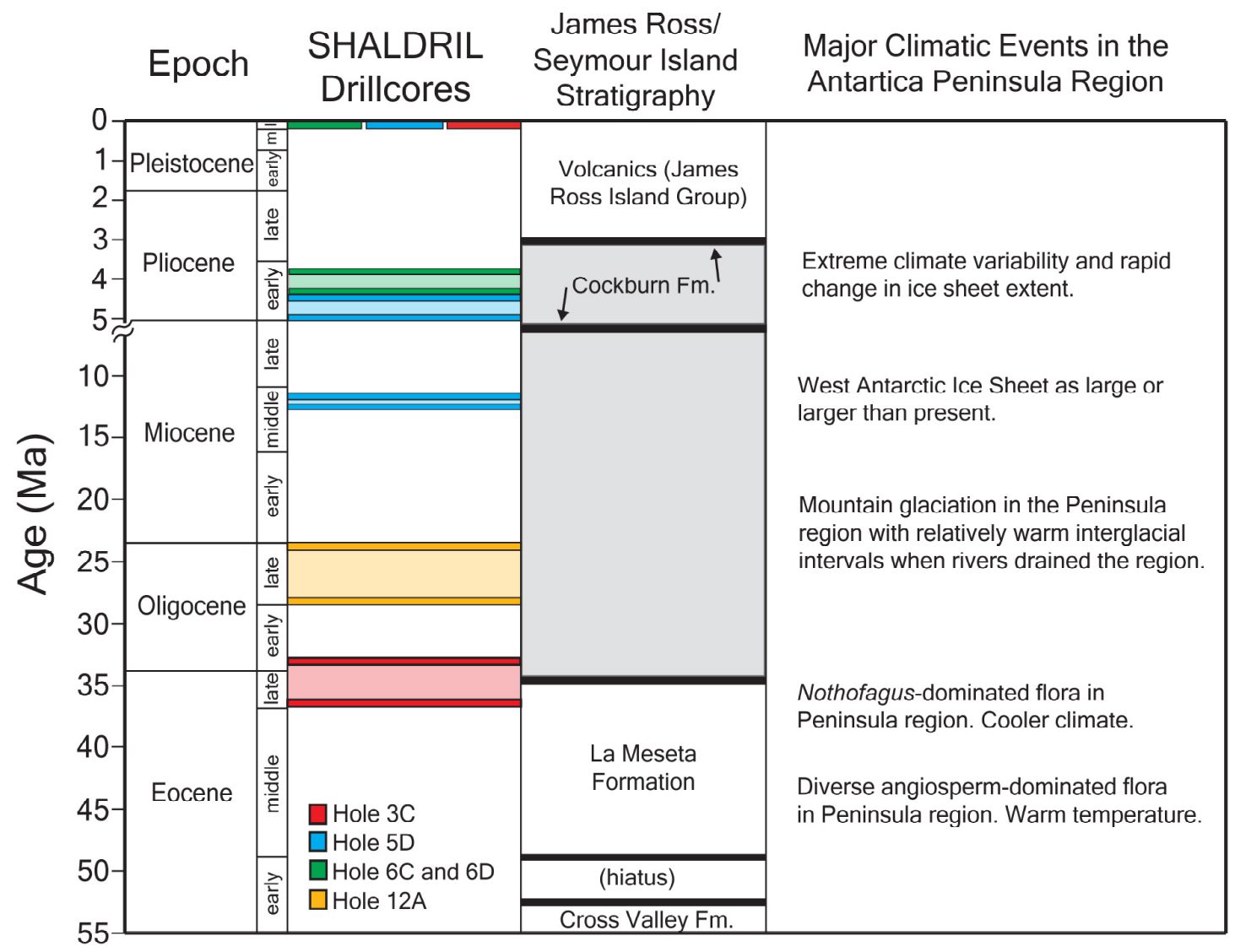

Figure 4. SHALDRIL II succeeded in recovering cores that record current gaps in the offshore stratigraphic record and intervals of time when significant changes in the climate, glacial setting and fauna and flora were taking place. This figure summarizes the stratigraphic intervals that were sampled. 
area show a thick wedge of southward dipping, acoustically laminated strata that onlap acoustic basement to the north (Figure 3). The younger strata of this wedge are cut by an unconformity that occurs near the seafloor. Otherwise, there are no apparent breaks in the section. The overall stratigraphic architecture is characterized by laterally continuous reflections and alternating strong and weaker reflections that form prominent cycles. The stronger reflections are interpreted as condensed sections and were the drilling targets for this phase of the program.

Since there was no pre-established age model for the Joinville Plateau, the first drill site sampled the middle part of the section (Figure 3). Site NBP0602A-5 sampled 9 meters of middle Miocene muddy sand. The second site (NBP0602A-6) was drilled at a location higher in the section and sampled 20 meters of Pliocene muddy sand. The third site (NBP06-12) sampled 4 meters of lithified muddy sand of late Oligocene age.

The stratigraphic section that was sampled along the southern margin of the Joinville Plateau lacks glacial unconformities, which indicates that these strata were deposited seaward of the maximum extent of ice sheet grounding on the plateau. Rather, the stratigraphic section appears to be relatively complete and is one of the most complete post-Eocene sections anywhere in Antarctica.

Ongoing research is aimed at improving our understanding of the changes in climate, glacial setting, and fauna and flora that took place as the Antarctic Peninsula was being glaciated. This is an international effort, currently involving scientists from the United States, the United Kingdom, Germany and Poland. The area is ideally suited for future drilling expeditions that would yield an even more complete late Paleogene and Neogene stratigraphic record.

\section{Summary}

SHALDRIL was successful in producing drill core that sampled time intervals that are poorly understood in terms of the glacial and climatic history of the Antarctic Peninsula. These include the uppermost Eocene to lowermost Oligocene, late Oligocene, middle Miocene and lower Pliocene (Figure 4). Ongoing research on the sediment cores collected during SHALDRIL II involves an international effort and includes detailed sedimentology, clay mineralogy, palynology, and micropaleontology.

Acknowledgements. We thank the people of the NBP and RPSC for helping to make SHALDRIL possible, and particularly Jay Ardai, Andy Frazer, Ashley Lowe, and Leon Holloway. This work is supported by NSF-OPP under Grant No. 0125922. We thank Alan Vaughan and Peter Sadler for their helpful reviews of this paper.

\section{References}

Anderson, J. B. (1999), Antarctica Marine Geology, Cambridge University Press, Cambridge, England, 289 p.

Anderson, J. B., S. S. Shipp, and F. P. Siringan (1992), Preliminary seismic stratigraphy of the northwestern Weddell Sea Continental Shelf, in Recent Progress in Antarctic Earth Science edited by Y. Yoshida, K. Kaminuma, and K. Shiraishi,:pp. 603-612, Terra Scientific Publishing, Tokyo.

Sloan, B. J., L. A. Lawver, and J. B. Anderson (1995), Seismic stratigraphy of the Palmer Basin, in Geology and Seismic Stratigraphy of the Antarctic Margin, edited by A.K.Cooper, P.F. Barker, and G. Brancolini, pp. 235-260, American Geophysical Union, Antarctic Research Series, v. 68, Washington, D.C.

Zachos, J., M. Pagani, M. L. Sloan, E., Thomas., and K. Billups, (2001), Trends, rhythms, and aberrations in global climate $65 \mathrm{Ma}$ to Present, Science, 